\title{
Climate and $\mathrm{CO}_{2}$ modulate the $\mathrm{C}_{3} / \mathrm{C}_{4}$ balance and $\delta^{13} \mathrm{C}$ signal in simulated vegetation
}

\author{
O. Flores ${ }^{1}$, E. S. Gritti ${ }^{1,2}$, and D. Jolly ${ }^{2}$ \\ ${ }^{1}$ CEFE, UMR 5175 CNRS, 1919, route de Mende, 34293, Montpellier cedex 5, France \\ ${ }^{2}$ ISEM, UMR 5554 CNRS/Univ. Montpellier II, Case 61, 34095 Montpellier cedex 5, France
}

Received: 25 February 2009 - Published in Clim. Past Discuss.: 31 March 2009

Revised: 12 July 2009 - Accepted: 15 July 2009 - Published: 7 August 2009

\begin{abstract}
Climate and atmospheric $\mathrm{CO}_{2}$ effects on the balance between $\mathrm{C}_{3}$ and $\mathrm{C}_{4}$ plants have received conflicting interpretations based on the analysis of carbon isotopic fractionation $\left(\delta^{13} \mathrm{C}\right)$ in sediments. But, climate and $\mathrm{CO}_{2}$ effects on the $\mathrm{C}_{3} / \mathrm{C}_{4}$ balance and $\delta^{13} \mathrm{C}$ signal are rarely addressed together. Here, we use a process-based model (BIOME4) to disentangle these effects. We simulated the vegetation response to climate and $\mathrm{CO}_{2}$ atmospheric concentration $\left(p_{\mathrm{CO}_{2}}\right)$ in two sites in which vegetation changed oppositely, with respect to $\mathrm{C}_{3}$ and $\mathrm{C}_{4}$ plants abundance, during the Last Glacial Maximum to Holocene transition. The $\mathrm{C}_{3} / \mathrm{C}_{4}$ balance and $\delta^{13} \mathrm{C}$ signal were primarily sensitive to temperature and $\mathrm{CO}_{2}$ atmospheric partial pressure. The simulated variations were in agreement with patterns observed in palaeorecords. Water limitation favoured $\mathrm{C}_{4}$ plants in case of large negative deviation in rainfall. Although a global parameter, $p_{\mathrm{CO}_{2}}$ affected the $\delta^{13} \mathrm{C}$ signal differently from one site to the other because of its effects on the $\mathrm{C}_{3} / \mathrm{C}_{4}$ balance and on carbon isotopic fractionation in $\mathrm{C}_{3}$ and $\mathrm{C}_{4}$ plants. Simulated Plant functional types (PFT) also differed in their composition and response from one site to the other. The $\mathrm{C}_{3} / \mathrm{C}_{4}$ balance involved different competing $\mathrm{C}_{3}$ and $\mathrm{C}_{4} \mathrm{PFT}$, and not homogeneous $\mathrm{C}_{3}$ and $\mathrm{C}_{4}$ poles as often assumed. Process-based vegetation modelling emphasizes the need to account for multiple factors when a palaeo- $\delta^{13} \mathrm{C}$ signal is used to reconstruct the $\mathrm{C}_{3} / \mathrm{C}_{4}$ balance.
\end{abstract}

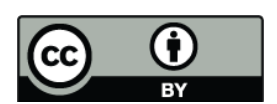

Correspondence to: O. Flores (olivierflores@free.fr)

\section{Introduction}

Studies of past vegetation combined with climate reconstruction help to identify important factors controlling vegetation dynamics. Due to their photosynthetic pathway, $\mathrm{C}_{3}$ and $\mathrm{C}_{4}$ plants show different carbon isotopic fractionation $\left(\delta^{13} \mathrm{C}\right)$, around -26 and $-13 \%$ respectively (Deines, 1980). The variability of $\delta^{13} \mathrm{C}$ in sediment records can thus inform on the relative abundance of $\mathrm{C}_{3}$ and $\mathrm{C}_{4}$ plants (Street-Perrott et al., 1997; Aucour et al., 1999; Wang et al., 2008). Based on this proxy, contrasted trends have been evidenced during the transition from the Last Glacial Maximum (LGM) to the Holocene. Interpretation of these trends led to conflicting conclusions regarding the relative influence of atmospheric $\mathrm{CO}_{2}$ and climate on the distribution of $\mathrm{C}_{3}$ and $\mathrm{C}_{4}$ plants (Street-Perrott et al., 1997; Huang et al., 2001). In this paper, we use a process-based vegetation model to disentangle the effects of climate and $\mathrm{CO}_{2}$ on the $\mathrm{C}_{3} / \mathrm{C}_{4}$ balance and $\delta^{13} \mathrm{C}$ signal.

In intertropical African highlands, sediment sequences in peatbogs revealed decreasing $\delta^{13} \mathrm{C}$, from high values during the LGM $(>-18 \%)$ to low values during the late Holocene $\left(-28.5<\delta^{13} \mathrm{C}<-19.5 \%\right.$; Aucour and Hillaire-Marcel, 1994; Aucour et al., 1999), indicating a decreasing contribution of $\mathrm{C}_{4}$ plants to vegetation production after the LGM. Consistently, pollen records highlighted a shift in vegetation at the end of the LGM, from grasslands comprising $\mathrm{C}_{4}$ species to montane forests with a majority of $\mathrm{C}_{3}$ trees (Jolly et al., 1997). In contrast, in continental central China, records revealed lower values of $\delta^{13} \mathrm{C}$ during the LGM than during the late Holocene (Gu et al., 2003; Wang et al., 2008). This trend was interpreted as a relative increase in the abundance of $\mathrm{C}_{4}$ species between these two periods, also consistent with pollen records. 
The shift from $\mathrm{C}_{4}$ to $\mathrm{C}_{3}$-dominated vegetation in intertropical Africa was primarily interpreted as triggered by the increase in atmospheric $\mathrm{CO}_{2}$ concentration $\left(p_{\mathrm{CO}_{2}}\right)$ after the LGM (Street-Perrott et al., 1997). Simulations also showed that a change in $p_{\mathrm{CO}_{2}}$ alone could drive such large vegetation changes (Cole and Monger, 1994; Jolly and Haxeltine, 1997). However, climatic conditions also changed drastically after the LGM, but with different regional patterns. In South American lakes, sequences revealed opposed signals in $\delta^{13} \mathrm{C}$ (Huang et al., 2001), from which the authors concluded that local climate controlled the abundance of $\mathrm{C}_{4}$ plants, since all sites shared the same $p_{\mathrm{CO}_{2}}$. In fact, opposite signals in the $\mathrm{C}_{3} / \mathrm{C}_{4}$ balance and $\delta^{13} \mathrm{C}$ can also occur under similar changes in mean climatic conditions. In intertropical Africa, cooler and dryer climatic conditions occurred during the LGM compared to late Holocene (Bonnefille et al., 1990; Bonnefille and Chalié, 2000). Similarly, in central China, vegetation faced cooler conditions (Zhang et al., 2003) and decreased monsoon intensity during the LGM (Liu et al., 2005).

It is thus likely that both climate and $p_{\mathrm{CO}_{2}}$ interact to control the $\mathrm{C}_{3} / \mathrm{C}_{4}$ balance and $\delta^{13} \mathrm{C}$ signal, in similar or opposite ways. Increased aridity can mimic effects of low $p_{\mathrm{CO}_{2}}$ for instance: stomatal closure due to water stress and/or low $p_{\mathrm{CO}_{2}}$ induce low concentration of $\mathrm{CO}_{2}$ in photosynthetic tissues, which favours photorespiration (the fixation of $\mathrm{O}_{2}$ instead of $\mathrm{CO}_{2}$ by the RuBisCo) and can alter photosynthesis. Because they decouple $\mathrm{CO}_{2}$ fixation from light reactions, $\mathrm{C}_{4}$ plants are less sensible to photorespiration than $\mathrm{C}_{3}$ plants (Sage, 2004). They can thus tolerate low stomatal conductance during warm hours as well as under low $p_{\mathrm{CO}_{2}}$. Another factor, the vegetation composition in plant functional types (PFT), is also likely to influence the $C_{3} / C_{4}$ balance. The proportion of $\mathrm{C}_{4}$ production represents the outcome of the competition between $\mathrm{C}_{3}$ and $\mathrm{C}_{4}$ plants; but whereas $\mathrm{C}_{4}$ plants are mostly grasses and sedges, $\mathrm{C}_{3}$ plants can be grasses, shrubs or trees with highly variable productivity.

In studies of palaeovegetation, the $\mathrm{C}_{3} / \mathrm{C}_{4}$ balance is generally estimated using a linear relationship between the vegetation $\delta^{13} \mathrm{C}$ and the proportion of $\mathrm{C}_{4}$ production (Gu et al., 2003; Wang et al., 2008), hereafter $r_{\mathrm{C}_{4}}$ : $\delta^{13} \mathrm{C}=r_{\mathrm{C}_{4}} \times \delta^{13} \mathrm{C}_{\mathrm{C}_{4}}+\left(1-r_{\mathrm{C}_{4}}\right) \times \delta^{13} \mathrm{C}_{\mathrm{C}_{3}}$ where $\delta^{13} \mathrm{C}_{\mathrm{C}_{4}}$, and $\delta^{13} \mathrm{C}_{\mathrm{C}_{3}}$ are often set to constant average values of $\delta^{13} \mathrm{C}$ in $\mathrm{C}_{3}$ and $\mathrm{C}_{4}$ plants. However, climate and $p_{\mathrm{CO}_{2}}$ can have direct effects on $r_{\mathrm{C}_{4}}$ as discussed above, as well as on $\delta^{13} \mathrm{C}_{\mathrm{C}_{3}}$ and $\delta^{13} \mathrm{C}_{\mathrm{C}_{4}}$ (Lloyd and Farquhar, 1994; Wang et al., 2008). Reconstructing the $\mathrm{C}_{3} / \mathrm{C}_{4}$ balance and interpreting the $\delta^{13} \mathrm{C}$ signal require to take account of these effects. But decoupling climate and $p_{\mathrm{CO}_{2}}$ effects is difficult in empirical studies. Process-based models of vegetation dynamics can then help address this issue because they explicitly model physiological processes as well the vegetation composition in plant functional types.

In this study, we use a process-based equilibrium model (BIOME4, Haxeltine and Prentice, 1996; Kaplan et al., 2002) to simulate the effects of climate and $p_{\mathrm{CO}_{2}}$ on the $\mathrm{C}_{3} / \mathrm{C}_{4}$ balance and $\delta^{13} \mathrm{C}$ signal in the vegetation. The $\mathrm{C}_{3} / \mathrm{C}_{4}$ balance is characterized by the proportion of estimated net primary production (NPP) due to $\mathrm{C}_{4} \mathrm{PFT}\left(r_{\mathrm{C}_{4}}\right) . \quad \delta^{13} \mathrm{C}$ is simulated as the NPP-weighted mean of $\delta^{13} \mathrm{C}$ of $\mathrm{C}_{3}$ and $\mathrm{C}_{4}$ PFT. The responses of these two variables to deviation in climatic conditions and to $p_{\mathrm{CO}_{2}}$ are investigated in two sites with contrasted vegetation history: one in the intertropical African highlands in Burundi, and one on the central Loess plateau in China. We specifically address the following questions: (I) is climate or $p_{\mathrm{CO}_{2}}$ the main forcing on the $\mathrm{C}_{3} / \mathrm{C}_{4}$ balance and $\delta^{13} \mathrm{C}$ signal? (II) which of climate or $p_{\mathrm{CO}_{2}}$ had a prevailing effect on vegetation change during the transition from the LGM?

\section{Methods}

\subsection{Site selection}

We focus on two sites differing in climatic conditions, current and past, and vegetation history in addition of being located in areas where reconstructions of climate and vegetation have been conducted. The two sites selected for comparison are Kuruyange in intertropical Africa (Burundi), and Lingtaï on the Chinese loess plateau.

Kuruyange lies in the interlacustrine highlands of Burundi and in the current altitudinal range of montane forests. These forests are present as fragments of broad-leaved forest inbetween cultivated and grazed land (Jolly et al., 1997). In Kuruyange, as in intertropical Africa overall, the vegetation of the LGM was essentially composed of cold grasses and scrub (Hamilton, 1982; Bonnefille and Riollet, 1988; Vincens, 1991; Taylor, 1992; Jolly and Haxeltine, 1997). After ca. $10-11 \mathrm{kyr} \mathrm{BP}$, this vegetation was progressively replaced by tropical montane forests (Coetzee, 1967; Hamilton, 1972; Taylor, 1990, 1993; Bonnefille et al., 1991, 1995; Vincens, 1991; Jolly et al., 1994). Pollen records from the area show that Poaceae and Cyperaceae, including $\mathrm{C}_{4}$ species, were abundant during the LGM. After $10 \mathrm{kyr} \mathrm{BP}$, grasses tend to disappear from records, whereas $\mathrm{C}_{3}$ trees become more abundant.

Lingtaï lies on the Loess plateau in central China. The vegetation in the area is a mixed forest of temperate coniferous and broad-leaved trees together with numerous grass species. Studies of $\delta^{13} \mathrm{C}$ in sediments showed that the vegetation at the LGM which was mostly steppe and desert vegetation, without $\mathrm{C}_{4}$ plants (Yu et al., 2000). During the Holocene, $\mathrm{C}_{4}$ plants became more abundant (Gu et al., 2003; Wang et al., 2008). 

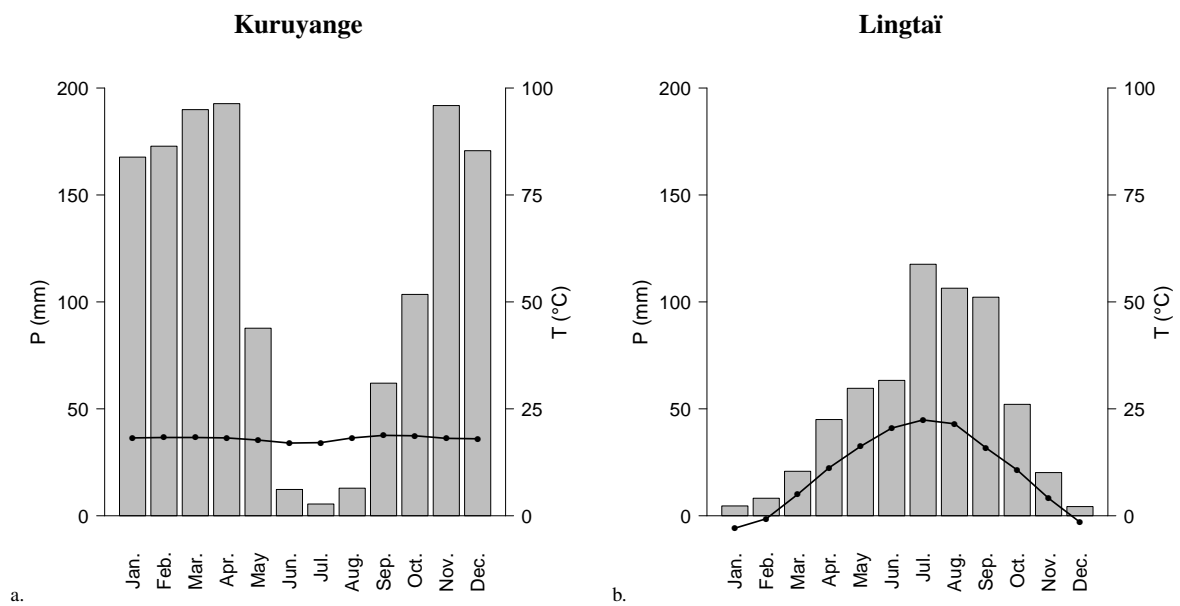

Fig. 1. Climatic diagram for (a) Kuruyange (Burundi; mean annual temperature, $\bar{T}=18.1^{\circ} \mathrm{C}$; annual rainfall amount, $P_{\mathrm{a}}=1380 \mathrm{~mm}$ ), and (b) Lingtaï (China; $\bar{T}=10.2^{\circ} \mathrm{C} ; P_{\mathrm{a}}=600 \mathrm{~mm}$ ). Data taken from nearest grid point in New et al. (2002).

\subsection{Current and past climate}

Climatic data were extracted from $10 \times 10$ climatic grids (New et al., 2002) considering the nearest point from sites location. Monthly values of rainfall in $\mathrm{mm} /$ month, mean temperature in ${ }^{\circ} \mathrm{C}$, and mean sunshine in $\%$ of day length were taken at $\left(-3.58^{\circ}, 29.75^{\circ}, 1850 \mathrm{~m}\right.$ a.s.l.) for Kuruyange, and $\left(35.03^{\circ}, 107.58^{\circ}, 1180 \mathrm{~m}\right.$ a.s.l.) for Lingtaï. Annual rainfall and mean annual temperature were respectively $1370 \mathrm{~mm}$, $18.0^{\circ} \mathrm{C}$ in Kuruyange, and $600 \mathrm{~mm}, 10.2^{\circ} \mathrm{C}$ in Lingtaï. $\mathrm{Ku}-$ ruyange has a typical equatorial climate with consistent monthly temperatures throughout the year, high rainfall from September to May followed by three warm and dry months during summer (Fig. 1a). Lingtaï has a continental climate with cold and dry winters and low rainfall concentrated in summer (Fig. 1b). The climate on the Loess plateau is largely controlled by the East Asian Monsoon (EAM) system (Balsam et al., 2004).

Deviation of climatic parameters were estimated at about $-4 \pm 2^{\circ} \mathrm{C}$ (Bonnefille et al., 1990) and $-450 \pm 250 \mathrm{~mm}$ (Bonnefille and Chalié, 2000) during the LGM in Burundi. In China, the mean annual temperature deviation ranges between -7 and $-10^{\circ} \mathrm{C}$ compared to current conditions in northern and central areas, and -4 and $-6^{\circ} \mathrm{C}$ in southern areas (Zheng et al., 1998). Rainfall was between 400 and $600 \mathrm{~mm}$ lower in regions under EAM influence and 200 to $300 \mathrm{~mm}$ lower in northern areas (Zheng et al., 1998).

\subsection{Simulated climate and $p_{\mathrm{CO}_{2}}$}

We used BIOME4 to analyse the $\mathrm{C}_{3} / \mathrm{C}_{4}$ balance response to various conditions of $p_{\mathrm{CO}_{2}}$ and climate. Climatic conditions were derived from current distributions of climatic parameters in order to deal with realistic scenarii. Soil parameters were obtained from the FAO database and kept constant in all simulations. Cloudiness (New et al., 2002) was kept constant as well. We conducted two types of simulations with varying climatic parameters and constant $p_{\mathrm{CO}_{2}}$ or varying $p_{\mathrm{CO}_{2}}$ and constant temperature and rainfall distributions.

First, current distributions of temperature and rainfall were modified to adjust the mean annual temperature $(\bar{T})$ and annual rainfall $\left(P_{a}\right)$ to chosen values, while keeping the overall shape of the distributions. Monthly means were adjusted as $T_{i}^{\prime}=T_{i}+\delta T$, where $T_{i}$ is the current mean temperature of month $i$, and $\delta T$ is the simulated deviation in mean annual temperature. Likewise, for a given deviation in rainfall $\left(\delta P_{a}\right)$, monthly rainfall were adjusted as $P_{i}^{\prime}=\left(1+\frac{\delta P_{a}}{P_{a}}\right) P_{i}$, where $P_{i}$ is the rainfall of month $i$ and $P_{\mathrm{a}}$ is the annual rainfall. $p_{\mathrm{CO}_{2}}$ was kept constant using two different values: the LGM value (180 ppmv, Monnin et al., 2001) and the current value ( $360 \mathrm{ppmv})$.

Second, we studied the influence of $p_{\mathrm{CO}_{2}}$ in fixed climatic conditions. Responses to $p_{\mathrm{CO}_{2}}$ were simulated by changing $p_{\mathrm{CO}_{2}}$ gradually from 180 to $360 \mathrm{ppmv}$. Two sets of climatic conditions were used: current climatic conditions ( $\delta T=0$ and $\delta P_{a}=0$, Fig. 1$)$ and average LGM conditions (Kuryange: $\delta T=-4^{\circ} \mathrm{C}, \delta P_{a}=-450 \mathrm{~mm}$; Lingtaï: $\delta T=-6^{\circ} \mathrm{C}$, $\left.\delta P_{a}=-400 \mathrm{~mm}\right)$.

\subsection{Model description}

BIOME4 (Kaplan et al., 2002) is a process-based equilibrium model for terrestrial vegetation of the BIOME family (Prentice et al., 1992; Haxeltine and Prentice, 1996). The inputs fed in the model are monthly temperatures, rainfalls and cloudiness, absolute minimal temperatures, soil texture, latitude, atmospheric pressure through altitude and $p_{\mathrm{CO}_{2}}$. Incoming solar radiation is calculated using current orbital parameters and average albedo. The model uses a two-layer description of soil, with different texture and depth. Run-off 
is evaluated, but lateral fluxes are not redistributed. Routines are included to approximate additional risks due to canopy fire and snow.

The models simulates 13 plant functional types (PFT) primarily constrained by absolute bioclimatic tolerance limits, such as the minimal supported number of growing days over $5^{\circ} \mathrm{C}$ (Table 1). These constraints determine the set of NPP that are potentially present given climatic parameters. A growth procedure then optimizes the NPP and the optimal leaf area index of each PFT in this set. Growth is estimated using a photosynthesis model coupling water and carbon fluxes in the plant (Haxeltine et al., 1996). Water fluxes in the model depend on soil water availability and evapotranspiration of soil and plants. Evapo-transpiration at the plant level is controlled by canopy conductance which is integrated from stomatal conductance. Stomatal conductance controls the ratio of intercellular to atmospheric $\mathrm{CO}_{2}$ concentration $\left(\frac{c_{i}}{c_{a}}\right)$ and thus the availability of $\mathrm{CO}_{2}$ for photosynthesis. Ten PFT out of 13 are exclusively $\mathrm{C}_{3}$, one exclusively $\mathrm{C}_{4}$, and two may use either pathway (temperate grass and woody desert type, Table 1).

We used a revised version of BIOME4 with enhanced carbon isotopic discrimination compared to previous versions (Hatté and Guiot, 2005). The discrimination model originally followed Lloyd and Farquhar (1994) for $\mathrm{C}_{3}$ and $\mathrm{C}_{4}$ plants: it estimates $\Delta_{A}$, the total discrimination against ${ }^{13} \mathrm{CO}_{2}$ during carbon assimilation from the atmosphere to photosynthetates. The $\mathrm{C}_{3}$ and the $\mathrm{C}_{4}$ photosynthetic pathways are considered separately (Lloyd and Farquhar, 1994; Kaplan et al., 2002). Revisions by Hatté and Guiot (2005) included a lower limit on $\frac{c_{i}}{c_{a}}$ in $\mathrm{C}_{3}$ PFT to avoid situations of stomatal closure. The revised version also takes into account all potentially present PFT, not only the dominant as previously, and weight discrimination by the estimated NPP which accounts for the net amount of stored carbon. Finally, discrimination during photosynthesis was refined by taking temperature influence into account (see Hatté and Guiot, 2005, for details).

We studied two response variables: (I) the fraction of NPP produced by $\mathrm{C}_{4}$ PFT: $r_{\mathrm{C}_{4}}=\frac{\sum_{\mathrm{C}_{4}} \text { NPP }}{\sum \mathrm{NPP}}$ where the sum is on the three obligate or facultative $\mathrm{C}_{4}$ PFT in numerator and on all PFT in denominator (Table 1), and (II) the carbon isotopic fractionation in vegetation $\left(\delta^{13} \mathrm{C}\right) \cdot \delta^{13} \mathrm{C}$ was obtained from $\Delta_{A}$ as $\delta^{13} \mathrm{C}=\frac{\delta_{\mathrm{atm}}-\Delta_{A}}{1+\Delta_{A}}$ where $\delta_{\mathrm{atm}}$ is the fixed atmospheric value $(-8 \% 0)$. In BIOME4, $\Delta_{A}$ is the NPP-weighted discrimination by all PFT.

\section{Results}

\subsection{Carbon isotopic fractionation in $\mathrm{C}_{3}$ and $\mathrm{C}_{4}$ PFT}

Carbon isotopic fractionation varied over separated ranges, between -32.9 and $-24.5 \%$ in $\mathrm{C}_{3}$ PFT, and between -18.9 and $-8.9 \%$ in $\mathrm{C}_{4}$ PFT, when all simulations were considered. These values are consistent with reported values in the literature for these two poles (O'Leary, 1988).

\subsection{Variation in $r_{\mathrm{C}_{4}}$ and $\delta^{13} \mathrm{C}$ from LGM to current con- ditions}

The simulated proportion of $\mathrm{C}_{4} \mathrm{NPP}\left(r_{\mathrm{C}_{4}}\right)$ was $6 \%$ at $\mathrm{Ku}-$ ruyange and $0 \%$ at Lingtaï in average LGM conditions (Table 2). From LGM to current conditions, $r_{\mathrm{C}_{4}}$ increased at the two sites (Kuruyange: $+14 \%$, Lingtaï: $+23 \%$, (Table 2 ), although $r_{\mathrm{C}_{4}}$ decreased with increasing $p_{\mathrm{CO}_{2}}$ under constant climate (Fig. 2a and 2b). Negative variation in $r_{\mathrm{C}_{4}}$ were obtained at Kuruyange at the upper bound of climatic parameters $(-22 \%$, Table 2$)$ whereas the variation was positive in Lingtaï over the whole range of parameters.

Regarding $\delta^{13} \mathrm{C}$, a variation of $-3.2 \%$ was simulated at Kuruyange and $+2.6 \%$ at Lingtaï (Table 2). In both sites, the sign of variation was consistent over the range of climatic parameters for LGM (Table 2). At Kuruyange, $\delta{ }^{13} \mathrm{C}$ responded to $p_{\mathrm{CO}_{2}}$ similarly in LGM and current climatic conditions (Fig. 2a). In contrast, the response at Lingtaï differed with respect to climatic conditions: $\delta^{13} \mathrm{C}$ increased from LGM to current climate (Fig. 2b).

To quantify the relative effects of climate and $p_{\mathrm{CO}_{2}}$, we decompose the variation of $\delta^{13} \mathrm{C}$ in one signal due to deviating climatic parameters only, and one signal due to increasing $p_{\mathrm{CO}_{2}}$ under constant climate. At Kuruyange, the climate signal was $+1.4 \%$ [ $[+2.8,-1.9]$ with $p_{\mathrm{CO}_{2}}$ kept at $180 \mathrm{ppmv}$, and $+0.3[+1.6,-2.6]$ at $360 \mathrm{ppmv}$. The $p_{\mathrm{CO}_{2}}$ signal was $-3.5 \%$ $[-3.4,-4.0]$ in LGM conditions, and $-4.6 \%$ in current climatic conditions. In Lingtaï, climate and $p_{\mathrm{CO}_{2}}$ had more contrasted effects (Fig. 2b): the climate signal was $+6.7 \%$ [ $[+8.6$, $+6.2]$ at 180 pppmv and $+6.8 \%[+9.3,+5.1]$ at 360 pppmv. The $p_{\mathrm{CO}_{2}}$ signal was $-4.2 \%[-4.7,-3.1]$ in LGM conditions, and $-4.1 \%$ in current conditions.

\subsection{Response to climate at fixed $p_{\mathrm{CO}_{2}}$}

Changes in rainfall had weak effects on $r_{\mathrm{C}_{4}}$ at both sites (Fig. 3). At Kuruyange, $r_{\mathrm{C}_{4}}$ hardly responded to deviation in rainfall, except in case of large negative deviation $\left(\delta P_{a}<-500 \mathrm{~mm}\right.$, Fig. 3a and c). At Lingtaï, negative rainfall deviation below $-300 \mathrm{~mm}$ favoured $\mathrm{C}_{4}$ plants at $360 \mathrm{ppmv}$ (Fig. 3b). Increasing temperature implied higher $\mathrm{C}_{4} \mathrm{NPP}$ in both sites. Low $p_{\mathrm{CO}_{2}}$ favoured $\mathrm{C}_{4}$ plants at both sites: $r_{\mathrm{C}_{4}}$ reached $45 \%$ at Kuruyange at current $p_{\mathrm{CO}_{2}}$ (Fig. 3a), and $61 \%$ at LGM level (Fig. 3c). At Lingtaï, these figures were respectively $43 \%$ and $85 \%$ (Fig. $3 \mathrm{~b}$ and d). No $\mathrm{C}_{4}$ $\mathrm{NPP}$ occurred below $-5^{\circ} \mathrm{C}$ of temperature deviation at $\mathrm{Ku}-$ ruyange (Fig. 2c), whatever the deviation in rainfall (Fig. 3a and c). At Lingtaï, the threshold on $r_{\mathrm{C}_{4}}$ was lower, about $-7^{\circ} \mathrm{C}$ (Fig. 2d).

The response of $\delta^{13} \mathrm{C}$ showed similar patterns compared to $r_{\mathrm{C}_{4}}$ (Fig. 4). The $\delta^{13} \mathrm{C}$ of the simulated vegetation increased with increasing temperature and responded weakly 
Table 1. Characteristics of Plant Functional Types (PFT) in BIOME4, taken from BIOME3 (Haxeltine et al., 1996). Phe.: phenology; $E$, evergreen; $S$, summergreen; $R$, raingreen; $g_{C}$ : maximal value for minimum canopy conductance; $E_{\max }$ : maximum value of supported daily transpiration rate; $S M_{\text {out }}$ : soil moisture below which raingreen leaves drop; $S M_{\text {in }}$ : soil moisture above which raingreen leaves appear; $R_{\text {top }}$ : fraction of roots in top soil layer, $30 \mathrm{~cm}$ from Jackson et al. (1996); LL: expected leaf longevity in months; GDD5: annual growing degree-days (GDD) above base temperatures of 5 and $0^{\circ} \mathrm{C}$ required for full leaf out; P.P.: photosynthetic pathway; $\mathrm{C}_{3}$, $\mathrm{C}_{4}$, or both.

\begin{tabular}{|c|c|c|c|c|c|c|c|c|c|c|c|}
\hline Label & Type & Phe. & $g_{C}$ & $E_{\max }$ & $S M_{\text {out }}$ & $S M_{\mathrm{in}}$ & $R_{\text {top }}$ & LL & $\mathrm{GDD}_{5}$ & $\mathrm{GDD}_{0}$ & P.P. \\
\hline tet & Tropical evergreen tree & $\mathrm{E}$ & 0.5 & 10 & & & 0.69 & 18 & & & $\mathrm{C}_{3}$ \\
\hline tdt & Tropical drought-deciduous tree & $\mathrm{R}$ & 0.5 & 10 & 0.5 & 0.6 & 0.70 & 9 & & & $\mathrm{C}_{3}$ \\
\hline tee & Temperate broadleaved evergreen tree & $\mathrm{E}$ & 0.2 & 4.8 & & & 0.67 & 18 & & & $\mathrm{C}_{3}$ \\
\hline ted & Temperate deciduous tree & $\mathrm{S}$ & 0.8 & 10 & & & 0.65 & 7 & 200 & & $\mathrm{C}_{3}$ \\
\hline $\cot$ & Cool conifer tree & $\mathrm{E}$ & 0.2 & 4.8 & & & 0.52 & 30 & & & $\mathrm{C}_{3}$ \\
\hline bet & Boreal evergreen tree & $\mathrm{E}$ & 0.5 & 4.5 & & & 0.83 & 24 & & & $\mathrm{C}_{3}$ \\
\hline bdt & Boreal deciduous tree & $\mathrm{S}$ & 0.8 & 10 & & & 0.83 & 24 & 200 & & $\mathrm{C}_{3}$ \\
\hline teg & Temperate grass & $\mathrm{R}$ & 0.8 & 6.5 & 0.2 & 0.3 & 0.83 & 8 & & 100 & $\mathrm{C}_{3} / \mathrm{C}_{4}$ \\
\hline $\operatorname{trg}$ & Tropical grass & $\mathrm{R}$ & 0.8 & 8 & 0.2 & 0.3 & 0.57 & 10 & & & $\mathrm{C}_{4}$ \\
\hline wde & Woody desert type & $\mathrm{E}$ & 0.1 & 1 & & & 0.53 & 12 & & & $\mathrm{C}_{3} / \mathrm{C}_{4}$ \\
\hline tsh & Tundra shrub & $\mathrm{E}$ & 0.8 & 1 & & & 0.93 & 8 & & & $\mathrm{C}_{3}$ \\
\hline che & Cold herbaceous type & $\mathrm{S}$ & 0.8 & 1 & & & 0.93 & 8 & & 25 & $\mathrm{C}_{3}$ \\
\hline lfo & Lichen/forb & $\mathrm{E}$ & 0.8 & 1 & & & 0.93 & 8 & & & $\mathrm{C}_{3}$ \\
\hline
\end{tabular}

Kuruyange
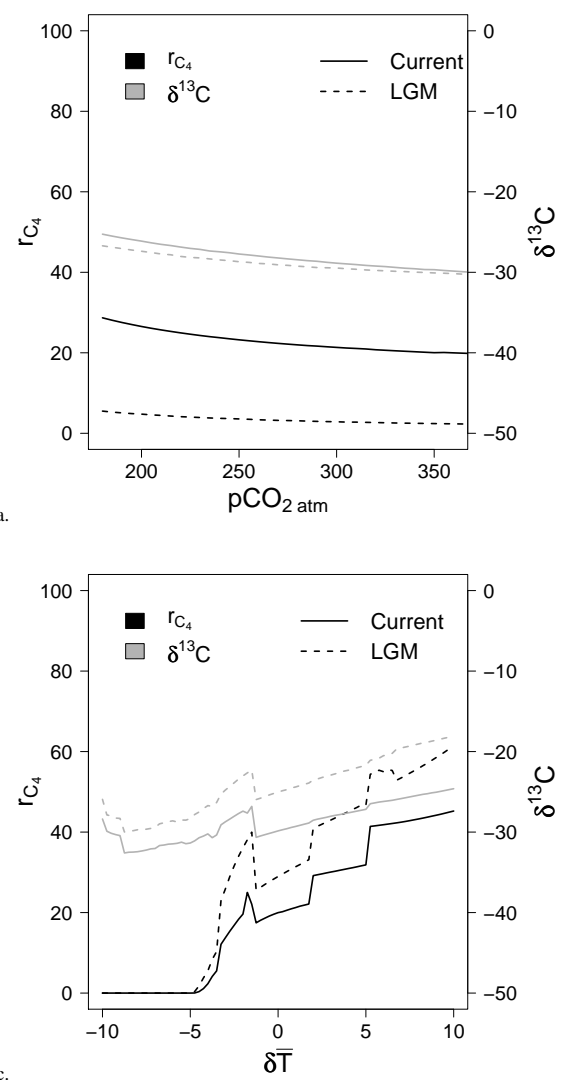

Lingtaï
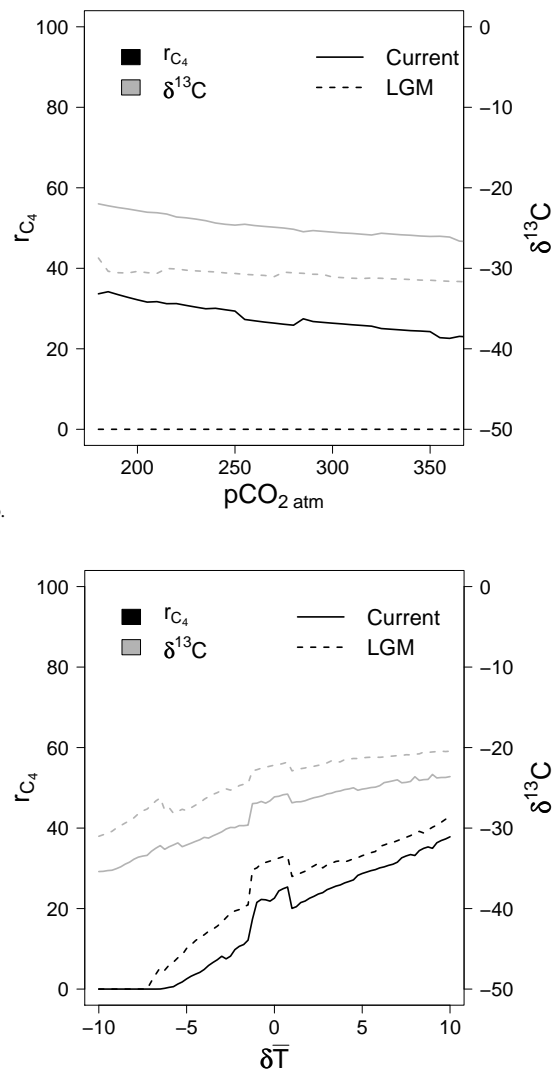

Fig. 2. Top: Simulated response profile of the proportion of $\mathrm{C}_{4} \mathrm{NPP}\left(r_{\mathrm{C}_{4}}\right.$, black lines) and carbon isotope fractioning $\left(\delta^{13} \mathrm{C}\right.$, gray lines) to $p_{\mathrm{CO}_{2}}$ at Kuruyange (Burundi, a) and Lingtaï (China, b). Solid and dotted lines correspond to current climatic conditions $\left(\delta T=0, \delta P_{a}=0\right)$, and mean LGM climatic conditions respectively. Bottom: Simulated response profile of $r_{\mathrm{C}_{4}}$ (black lines) and $\delta^{13} \mathrm{C}(\mathrm{gray}$ lines) to deviation in mean annual temperature $(\delta T)$ at Kuruyange (c) and Lingtaï (d). Solid and dotted lines correspond to current $p_{\mathrm{CO}_{2}}$ and rainfall, and mean LGM climatic conditions respectively. 
Table 2. Simulated proportion of net primary production by $\mathrm{C}_{4}$ plants $\left(r_{\mathrm{C}_{4}}\right)$ and carbon isotopic fractionation $\delta^{13} \mathrm{C}$ at Kuruyange $(\mathrm{Burundi})$ and Lingtaï (China) in conditions of the Last Glacial Maximum (LGM: $p_{\mathrm{CO}_{2}}=180 \mathrm{ppmv}$; Kuryange: $\delta T=-4 \pm 2^{\circ} \mathrm{C}, \delta P_{a}=-450 \pm 250 \mathrm{~mm}$; Lingtaï: $\left.\delta T=8 \pm 2{ }^{\circ} \mathrm{C}, \delta P_{a}=-400 \pm 100 \mathrm{~mm}\right)$ and in current conditions $\left(p_{\mathrm{CO}_{2}}=360 \mathrm{ppmv} ; \delta T=0{ }^{\circ} \mathrm{C}, \delta P_{a}=0 \mathrm{~mm}\right)$. Numbers in brackets indicate the range of simulated values obtained using extreme values for LGM conditions (see text).

\begin{tabular}{lllll}
\hline & \multicolumn{2}{c}{ Kuruyange } & \multicolumn{2}{l}{ Lingtaï } \\
\cline { 2 - 5 } & $r_{\mathrm{C}_{4}}(\%)$ & $\delta^{13} \mathrm{C}(\%)$ & $r_{\mathrm{C}_{4}}(\%)$ & $\delta^{13} \mathrm{C}(\%)$ \\
\hline LGM & $6[0,36]$ & $-26.7[-28.0,-23.4]$ & $0[0,5]$ & $-28.7[-30.6,-28.1]$ \\
Current & 20 & -29.9 & 23 & -26.1 \\
$\Delta$ & $+14[+20,-22]$ & $-3.2[-1.9,-6.5]$ & $+23[+23,+17]$ & $+2.6[+4.5,+2.0]$ \\
\hline
\end{tabular}
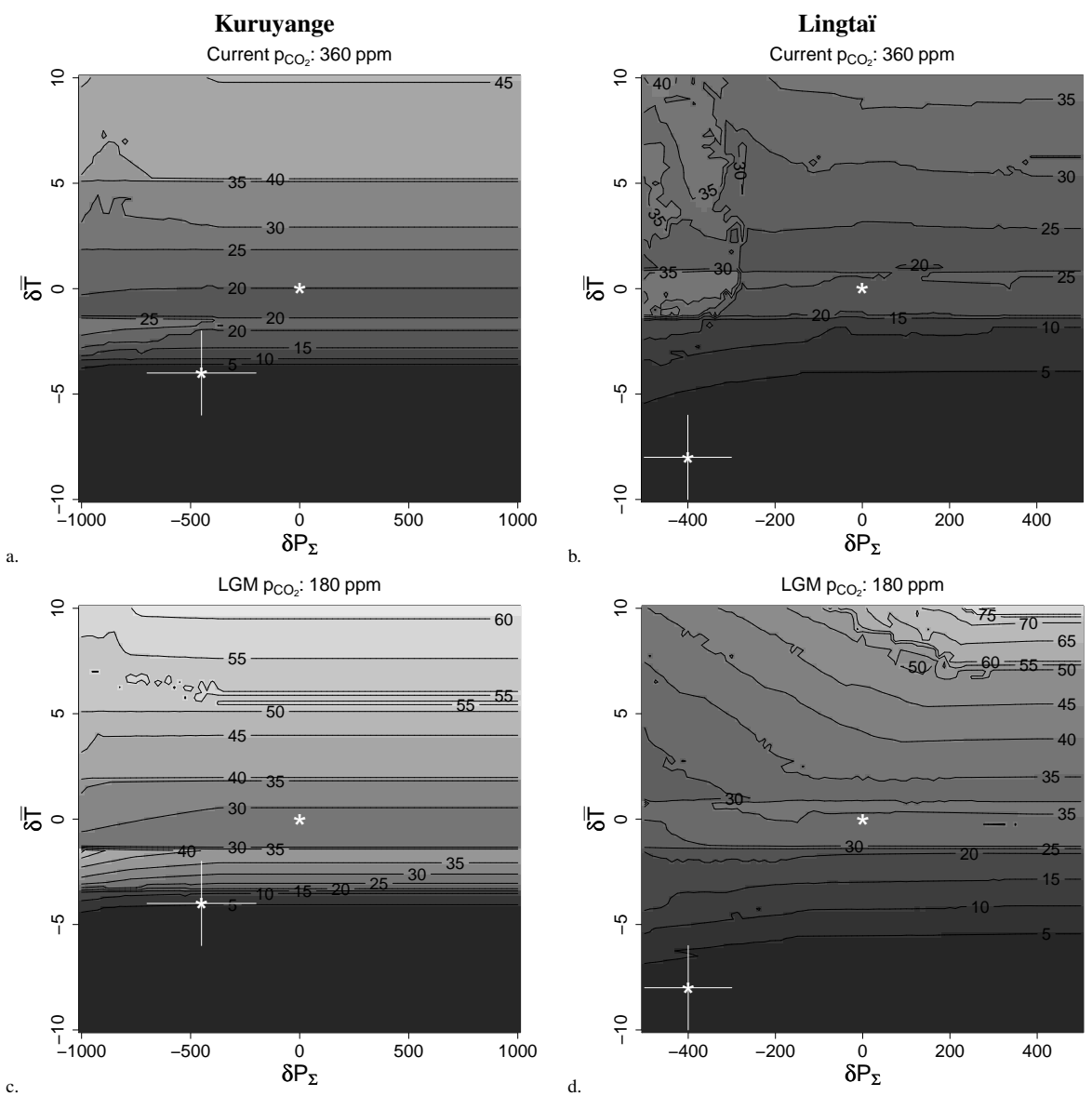

Fig. 3. Proportion of total NPP produced by $\mathrm{C}_{4}$ PFT $\left(r_{\mathrm{C}_{4}}\right.$, in $\left.\%\right)$ simulated at Kuruyange (Burundi, a and c) and Lingtaï (China, b and d) as a function of deviation in mean annual temperature $(\delta T)$ and deviation in annual rainfall $\left(\delta P_{a}\right)$ with respect to current values. Two cases of $p_{\mathrm{CO}_{2}}$ are presented: current level (360 ppm, a and b), and Last Glacial Maximum level (LGM, $180 \mathrm{ppm}, \mathbf{c}$ and d). Black lines indicates isolines in $r_{\mathrm{C}_{4}}$ value with a $5 \%$-step. Asterisks indicate current $\left(\delta T=0, \delta P_{a}=0\right)$ and LGM climatic conditions. White lines indicate climatic parameters range for the LGM, taken from the literature.

to change in rainfall except for large negative deviations. Low $p_{\mathrm{CO}_{2}}$ induced high values of $\delta^{13} \mathrm{C}$ (Fig. $4 \mathrm{c}$ and d) compared to the current level (Fig. $4 \mathrm{a}$ and b). Simulated values ranged between -33 and $-23 \%$ at Kuruyange at current $p_{\mathrm{CO}_{2}}$ (Fig. 4a), and between -30 and $-18 \%$ for the LGM level (Fig. 4c). At Lingtaï, these ranges were respectively $[-35,-23] \%$ and $[-31,-19] \%$ (Fig. $4 b$ and $4 d$ ).

\subsection{Vegetation composition in PFT}

The composition of the vegetation showed important changes in response to temperature. Increased $p_{\mathrm{CO}_{2}}$ from LGM to current level had an overall fertilization effect, except on the tropical grass PFT (obligate $\mathrm{C}_{4}$; Fig. 5). Tree PFT had the highest NPP (tet, tft, tee, cot; Fig. 5a) at Kuruyange in current conditions, followed by the "temperate grass" type (teg; 

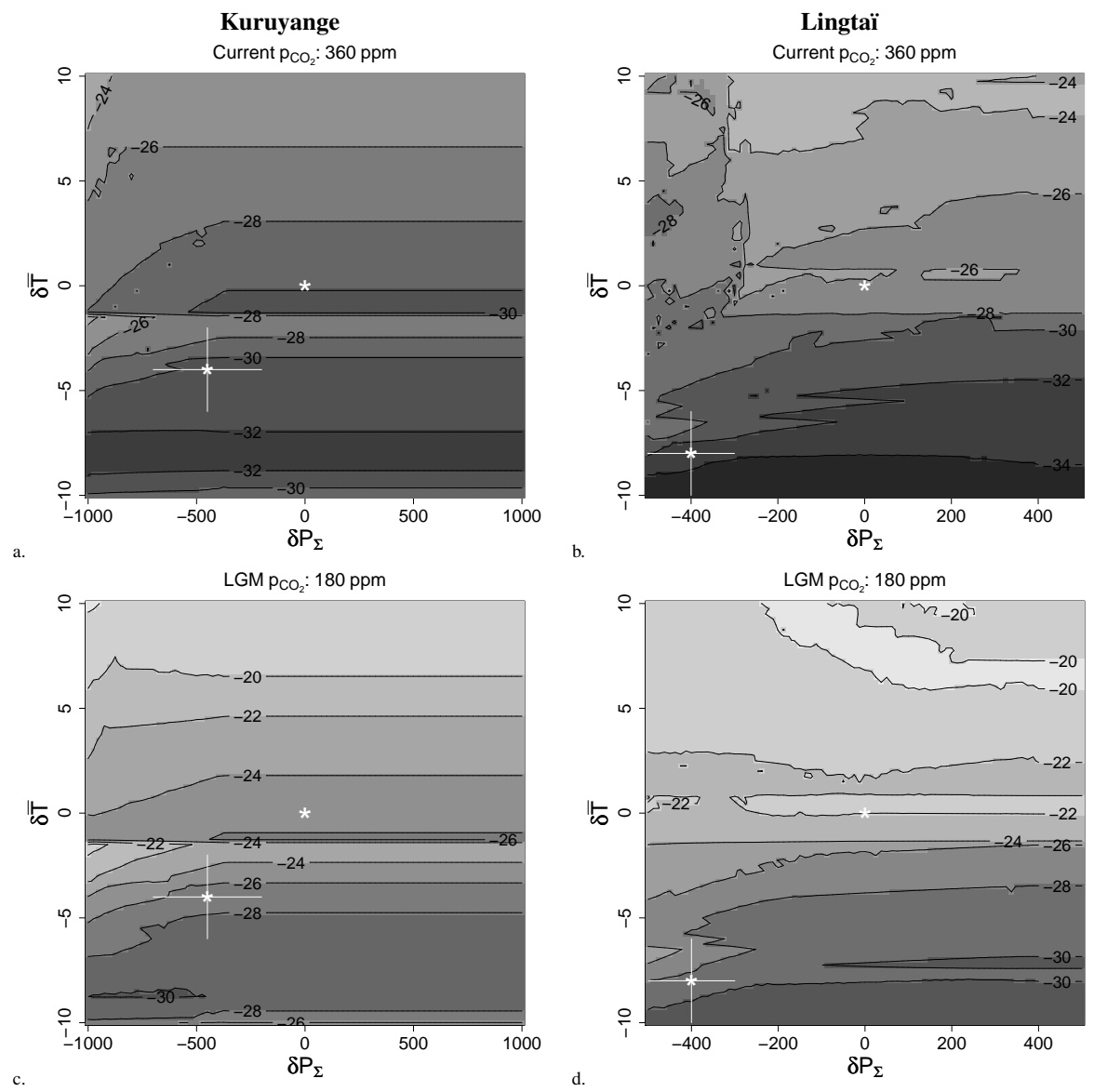

Fig. 4. Simulated carbon isotope fractioning $\left(\delta^{13} \mathbf{C}\right)$ in vegetation at Kuruyange (Burundi, a and c) and Lingtaï (China, b and d) as a function of deviation in mean annual temperature $(\delta T)$ and deviation in annual rainfall $\left(\delta P_{a}\right)$ with respect to current values. Two cases of $p_{\mathrm{CO}}$ are presented: current level ( $360 \mathrm{ppm}, \mathbf{a}$ and b), and Last Glacial Maximum level (LGM, $180 \mathrm{ppm}, \mathbf{c}$ and d). Asterisks indicate current $(\delta T=0$, $\left.\delta P_{a}=0\right)$ and LGM climatic conditions. White lines indicate climatic parameters range for the LGM, taken from the literature.

Fig. 5a) for $\delta T<-2^{\circ} \mathrm{C}$, and the "tropical grass" (trg) above for $\delta T>-2^{\circ} \mathrm{C}$. In LGM conditions, the "tropical grass" type (trg) was highly productive compared to tree PFT. In Lingtaï, the "temperate deciduous tree" type (ted; Fig. 5b) and the "temperate grass type" (teg) were highly productive. The "temperate deciduous tree" was the only present tree PFT when temperature deviated between -1 and $+1^{\circ} \mathrm{C}$. The "boreal tree" types (bet, bdt) occurred below $-1{ }^{\circ} \mathrm{C}$, and were replaced by the "cool conifer tree" type above $+1^{\circ} \mathrm{C}$.

\section{Discussion}

Vegetation modelling allowed to decouple the effects of climate and $p_{\mathrm{CO}_{2}}$ on the balance between $\mathrm{C}_{3}$ and $\mathrm{C}_{4}$ plants, and on the resulting $\delta^{13} \mathrm{C}$ signal. The model could reproduce actual trends in the abundance of $\mathrm{C}_{4}$ plants which are usually favoured at high temperature and in condition of low moisture and atmospheric $\mathrm{CO}_{2}$ concentration (Sage, 2004). Overall, our results evidenced a prevailing effect of climate over
$\mathrm{CO}_{2}$. Temperature was the most influencing factor on the $\mathrm{C}_{3} / \mathrm{C}_{4}$ balance, while rainfall influence was weaker. However, strong negative deviation in rainfall amount, of the magnitude observed during the LGM, could favour $\mathrm{C}_{4}$ plants. These results are consistent with studies of palaeo-sequences in central China (Zhang et al., 2003; Liu et al., 2005) and in central America (Huang et al., 2001) which concluded that local climate change was the main driver of the $\mathrm{C}_{3} / \mathrm{C}_{4}$ dynamics during the LGM-Holocene transition. The low temperature of the LGM limited $\mathrm{C}_{4}$ production of the simulated vegetation in China accordingly to empirical evidence (Zhang et al., 2003). In Africa, less limiting conditions during the LGM allowed $\mathrm{C}_{4}$ plants to sustain limited production. However, our results confirmed that low $p_{\mathrm{CO}_{2}}$ also shifted the balance in favour of $\mathrm{C}_{4}$ plants in the two studied sites. These findings are consistent with other studies which addresses the effects of both climate and $\mathrm{CO}_{2}$ simultaneously (Ehleringer et al., 1997; Boom et al., 2002). 

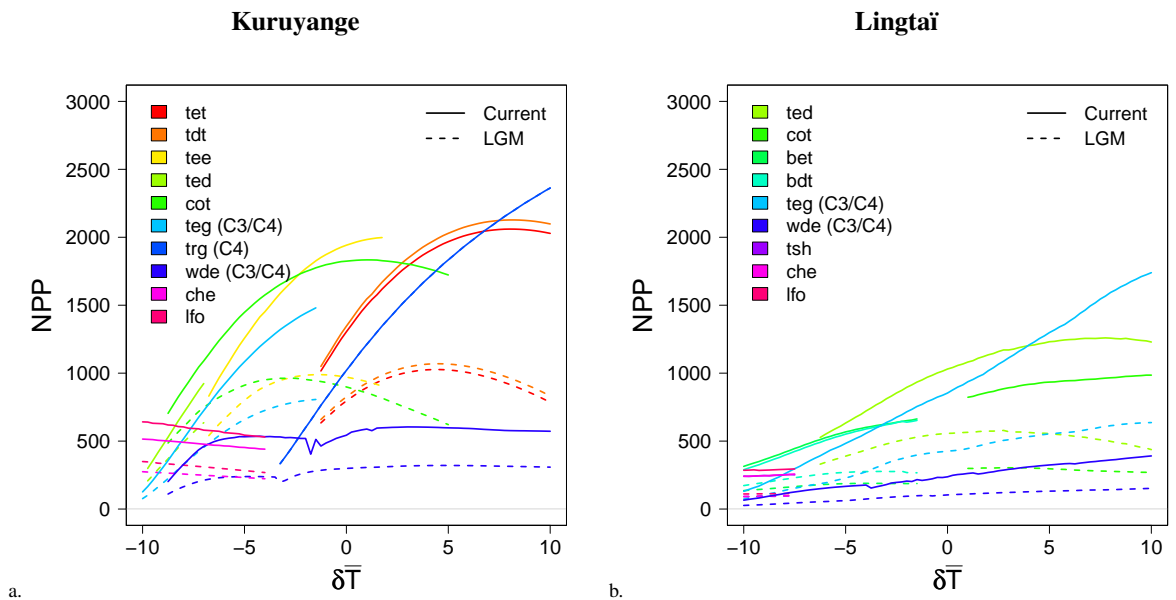

Fig. 5. Simulated Net Primary Production (NPP, in $\mathrm{gC} \cdot \mathrm{m}^{-2} \cdot \mathrm{yr}^{-1}$ ) of plant functional types (PFT) as a function of deviation in mean annual temperature $(\delta T)$ at Kuruyange (Burundi, a) and Lingtaï (China, b). Solid and dotted lines correspond to current $p_{\mathrm{CO}_{2}}$ and rainfall, and mean LGM climatic conditions respectively. PFT are labelled according to Table 1: tet, tropical evergreen tree; trt, tropical drought-deciduous tree; the, temperate broadleaved evergreen tree; tst, temperate deciduous tree; ctc, cool conifer tree; bec, boreal evergreen tree; bst, boreal deciduous tree; teg, temperate grass; tog, tropical grass; wde, woody desert type; tsh, tundra shrub; che, cold herbaceous type; lfo, lichen/forb.

The model reproduced the overall variation in the $\mathrm{C}_{3} / \mathrm{C}_{4}$ balance and $\delta^{13} \mathrm{C}$ following the transition from LGM to current conditions. The simulated $\delta^{13} \mathrm{C}$ signal matched the decrease in $\delta^{13} \mathrm{C}$ observed at Kuruyange (Aucour et al., 1999) and the increase observed at Lingtaï (Gu et al., 2003) following the transition from LGM to current conditions. Local conditions could thus lead to opposed effects on the $\delta^{13} \mathrm{C}$ signal, despite similar deviations in climatic parameters from the LGM to current conditions. Regarding the $\mathrm{C}_{3} / \mathrm{C}_{4}$ balance however, the simulated variation at Kuruyange was between $+20 \%$ and $-22 \%$, showing high sensitivity to incertitude in LGM climatic parameters. These results suggest that the deviation in mean temperature during the LGM was probably closer to the upper bound $\left(\delta T=-2^{\circ} \mathrm{C}\right.$, Bonnefille et al., 1990) than to the lower, as no $\mathrm{C}_{4}$ occurred at low temperature $\left(\delta T<-5^{\circ} \mathrm{C}\right)$ in Kuruyange.

Palaeosequences obtained in swamps in Burundi showed that grasses (Poaceae) and sedges (Cyperaceae) including $\mathrm{C}_{4}$ species dominated pollen records in the area during the LGM (Aucour et al., 1999). But the contribution of $\mathrm{C}_{4}$ plants during the LGM was probably higher in the swamp biomass than in the surrounding vegetation (Aucour et al., 1999). Our simulations suggest however that $\mathrm{C}_{4}$ plants represented no more than $36 \%$ of the vegetation. In Lingtaï, the simulations are consistent with $\mathrm{Gu}$ et al. (2003) who concluded that no $\mathrm{C}_{4}$ production occurred during the LGM, although uncorrected values of carbon isotopic fractionation were used in their reconstruction. Lower rainfall and $p_{\mathrm{CO}_{2}}$ could not lead to $\mathrm{C}_{4}$ plants expansion in the absence of favourable temperature condition.
Climate and $\mathrm{CO}_{2}$ both controlled the $\delta^{13} \mathrm{C}$ variation from LGM to current conditions. The transition from low $p_{\mathrm{CO}_{2}}$ during the LGM to higher current level implied a decrease in $\delta^{13} \mathrm{C}$ in both sites. But, this effect differed from one site to the other. These results show that, although $p_{\mathrm{CO}_{2}}$ is a global parameter, its influence differed between sites, because of its effects on the $\mathrm{C}_{3} / \mathrm{C}_{4}$ balance and carbon isotopic fractionation in $\mathrm{C}_{3}$ and $\mathrm{C}_{4}$ plants. In Kuruyange, the climate signal was lower than the $p_{\mathrm{CO}_{2}}$ signal, and the two strongly interacted. In contrast, in Lingtaï, the signal was stronger with climate than with $p_{\mathrm{CO}_{2}}$, which led to the overall simulated increase in $\delta^{13} \mathrm{C}$. The two effects however interacted less than in Kuruyange. Moreover, climate and $\mathrm{CO}_{2}$ effects on the $\mathrm{C}_{3} / \mathrm{C}_{4}$ balance were modulated by specific bioclimatic constraints limiting the potential composition of the vegetation in PFT at each site. Depending on the range of climatic conditions considered, the competition between $\mathrm{C}_{3}$ and $\mathrm{C}_{4}$ plants may involves PFT with different productivities. Consequently, the nature of PFT present at the site had strong effect on the reconstructed $\mathrm{C}_{3} / \mathrm{C}_{4}$ balance: a shift from low producing to high $\mathrm{C}_{3}$ PFT decreases the proportion of $\mathrm{C}_{4}$ NPP all other things being equal.

\section{Conclusions}

Process-based models allow to disentangle climate and $\mathrm{CO}_{2}$ impact on vegetation using a mechanistic approach. In the examples studied here, climate had a prevailing effect, with temperature imposing strong constraints of the $\mathrm{C}_{3} / \mathrm{C}_{4}$ balance, rainfall being influential in case of strong limitation. Atmospheric $\mathrm{CO}_{2}$ acted as an overall fertilizer of 
photosynthesis. However, its effects on the $\mathrm{C}_{3} / \mathrm{C}_{4}$ balance and $\delta^{13} \mathrm{C}$ signal depended on local conditions because of interaction with climatic and vegetation composition effects.

Acknowledgements. This paper is a contribution to the INCO-EU project (INCO-DC DG XII, ERB3514PL972473). We wish to thank J. Guiot for kindly providing us the code of the revised version of BIOME4, and A. Fayolle for her constructive comments.

Edited by: J. Guiot

\section{References}

Aucour, A. and Hillaire-Marcel, C.: Late Quaternary biomass changes from ${ }^{13} \mathrm{C}$ measurements in a highland peatbog from equatorial Africa (Burundi), Quaternary Res., 41, 225-233, 1994.

Aucour, A., Bonnefille, R., and Hillaire-Marcel, C.: Sources and accumulation rates of organic carbon in an equatorial peatbog (Burundi, East Africa) during the Holocene: carbon isotope constraints, Palaeogeogr., Palaeoclimatol., Palaeoecol., 150, 179_ 189, 1999.

Balsam, W., Ji, J., and Chen, J.: Climatic interpretation of the Luochuan and Lingtai loess sections, China, based on changing iron oxide mineralogy and magnetic susceptibility, Earth Planet. Sci. Lett., 223, 335-348, 2004.

Bonnefille, R. and Chalié, F.: Pollen-inferred precipitation timeseries from equatorial mountains, Africa, the last $40 \mathrm{kyr} \mathrm{BP}$, Global Planet. Change, 26, 25-50, 2000.

Bonnefille, R. and Riollet, G.: The Kashiru pollen sequence (Burundi), Palaeoclimatic implications for the last $40000 \mathrm{yr} \mathrm{BP}$ in tropical Africa, Quaternary Res., 30, 19-35, 1988.

Bonnefille, R., Roeland, J. C., and Guiot, J.: Temperature and rainfall estimates for the past 40000 years in equatorial Africa, Nature, 346, 347-349, 1990.

Bonnefille, R., Riollet, G., and Buchet, G.: Nouvelle séquence pollinique d'une tourbière de la crête Zaire-Nil (Burundi), Rev. Palaeobot. Palyno., 67, 315-330, 1991.

Bonnefille, R., Riollet, G., Buchet, G., Icole, M., Lafont, R., Arnold, M., and Jolly, D.: Glacial/interglacial record from intertropical Africa, high resolution pollen and carbon data at Rusaka, Burundi, Quaternary Sci. Rev., 14, 917-936, 1995.

Boom, A., Marchant, R., Hooghiemstra, H., and Damsté, J. S. S.: $\mathrm{CO}_{2}$ - and temperature-controlled altitudinal shifts of $\mathrm{C} 4-$ and C3-dominated grasslands allow reconstruction of palaeoatmospheric $p \mathrm{CO}_{2}$, Palaeogeogr., Palaeoclimatol., Palaeoecol., 177, 151-168, 2002.

Coetzee, J.: Pollen analytical studies in east and southern Africa, Palaeoeco. A., 3, 1-146, 1967.

Cole, D. R. and Monger, H. C.: Influence of atmospheric $\mathrm{CO}_{2}$ on the decline of $\mathrm{C} 4$ plants during the last deglaciation, Nature, 368 , 533-536, 1994

Deines, P.: The isotopic composition of reduced inorganic carbon, in: Handbook of Environmental Isotope Chemistry: the terrestrial environment, edited by Fritz, P. and Fontes, J., Elsevier, Amsterdam, 1, 329-406, 1980.

Ehleringer, J. R., Cerling, T. E., and Helliker, B. R.: C4 photosynthesis, atmospheric $\mathrm{CO}_{2}$, and climate, Oecologia, 112, 285-299, 1997.
Gu, Z. Y., Liu, Q., Xu, B., Han, J. M., Yang, S. L., Ding, Z. L., and Liu, T. S.: Climate as the dominant control on C-3 and C4 plant abundance in the Loess Plateau: Organic carbon isotope evidence from the last glacial-interglacial loess-soil sequences, Chinese Sci. Bull., 48, 1271-1276, 2003.

Hamilton, A.: The interpretation of pollen diagrams from highland Uganda, Palaeoeco. A., 7, 45-149, 1972.

Hamilton, A.: Environmental history of East Africa: a study of the Quaternary, Academic press, New York, 328 p., 1982.

Hatté, C. and Guiot, J.: Palaeoprecipitation reconstruction by inverse modelling using the isotopic signal of loess organic matter: application to the NuÃ Ÿloch loess sequence (Rhine Valley, Germany), Clim. Dynam., 25, 315-327, 2005.

Haxeltine, A. and Prentice, I.: BIOME3: An equilibrium terrestrial biosphere model based on ecophysiological constraints, availability, and competition among plant functional types, Global Biogeochem. Cy., 10, 693-709, 1996.

Haxeltine, A., Prentice, I., and Cresswell, I.: A coupled carbon and water flux model to predict vegetation structure, J. Veg. Sci., 7 , 651-666, 1996.

Huang, Y., Street-Perrott, F. A., Metcalfe, S. E., Brenner, M., Moreland, M., and Freeman, K. H.: Climate Change as the Dominant Control on Glacial-Interglacial Variations in C3 and C4 Plant Abundance, Science, 293, 1647-1651, 2001.

Jolly, D. and Haxeltine, A.: Effect of low glacial atmopsheric $\mathrm{CO}_{2}$ on tropical African montane vegetation, Science, 276, 786-788, 1997.

Jolly, D., Bonnefille, R., and Roux, M.: Numerical interpretation of a high resolution Holocene pollen record from Burundi, Palaeogeogr., Palaeoclimatol., Palaeoecol., 109, 357-370, 1994.

Jolly, D., Taylor, D., Marchant, R., Hamilton, A., Bonnefille, R., Buchet, G., and Riollet, G.: Vegetation dynamics in central Africa since $18000 \mathrm{yr}$ BP: pollen records from the interlacustrine highlands of Burundi, Rwanda and western Uganda, J. Biogeogr., 24, 495-512, 1997.

Kaplan, J. O., Prentice, I. C., and Buchmann, N.: The stable carbon isotope composition of the terrestrial biosphere: Modeling at scales from the leaf to the globe, Global Biogeochem. Cy., 16, 1-11, 2002.

Liu, W., Huang, Y., An, Z., Clemens, S. C., Li, L., Prell, W. L., and Ning, Y.: Summer monsoon intensity controls C4/C3 plant abundance during the last $35 \mathrm{ka}$ in the Chinese Loess Plateau: Carbon isotope evidence from bulk organic matter and individual leaf waxes, Palaeogeogr., Palaeoclimatol., Palaeoecol., 220, 243-254, 2005.

Lloyd, J. and Farquhar, G. D.: $13 \mathrm{C}$ discrimination during $\mathrm{CO}_{2}$ assimilation by the terrestrial biosphere, Oecologia, 99, 201-215, 1994.

Monnin, E., Indermuhle, A., Dallenbach, A., Fluckiger, J., Stauffer, B., Stocker, T. F., Raynaud, D., and Barnola, J.-M.: Atmospheric $\mathrm{CO}_{2}$ Concentrations over the Last Glacial Termination, Science, 291, 112-114, 2001.

New, M., Lister, D., Hulme, M., and Makin, I.: A high-resolution data set of surface climate over global land areas, Climate Res., 21, 1-25, 2002.

O'Leary, M. H.: Carbon Isotopes in Photosynthesis, Bioscience, 38, 328-336, 1988

Prentice, I. C., Cramer, W., Harrison, S. P., Leemans, R., Monserud, R. A., and Solomon, A. M.: A global biome model based on 
plant physiology and dominance, soil properties and climate, J. Biogeogr., 19, 117-134, 1992.

Sage, R. F.: The evolution of C4 photosynthesis, New Phyt., 161, 341-370, 2004.

Street-Perrott, F. A., Huang, Y., Perrott, R. A., Eglinton, G., Barker, P., Khelifa, L. B., Harkness, D. D., and Olago, D. O.: Impact of Lower Atmospheric Carbon Dioxide on Tropical Mountain Ecosystems, Science, 278, 1422-1426, 1997.

Taylor, D.: Late Quaternary pollen records from two Ugandan mires: evidence for environmental change in the Rukiga Highlands of southwest Uganda, Palaeogeogr., Palaeoclimatol., Palaeoecol., 80, 283-300, 1990.

Taylor, D.: Pollen evidence from Muchoya swamp, Rukiga Highlands (Uganda), for abrupt changes in vegetation during the last ca. 21000 years, B. Soc. Geol. Fr., 163, 77-82, 1992.

Taylor, D.: Environmental change in montane southwest Uganda: a pollen record for the Holocene from Ahakagyezi swamp, The Holocene, 3, 324-332, 1993.

Vincens, A.: Late Quaternary vegetation history of the SouthTanganyika Basin. Climatic implications in south central Africa, Palaeogeogr., Palaeoclimatol., Palaeoecol., 86, 207-226, 1991.
Wang, G., Feng, X., Han, J., Zhou, L., Tan, W., and Su, F.: Paleovegetation reconstruction using $\delta^{13} \mathrm{C}$ of Soil Organic Matter, Biogeosciences, 5, 1325-1337, 2008, http://www.biogeosciences.net/5/1325/2008/.

Yu, G., Chen, X., Ni, J., Cheddadi, R., Guiot, J., Han, H., Harrison, S. P., Huang, C., Ke, M., Kong, Z., Li, S., Li, W., Liew, P., Liu, G., Liu, J., Liu, Q., Liu, K., Prentice, I. C., Qui, W., Ren, G., Song, C., Sugita, S., Sun, X., Tang, L., Campo, E. V., Xia, Y., Xu, Q., Yan, S., Yang, X., Zhao, J., and Zheng, Z.: Palaeovegetation of China: a pollen data-based synthesis for the mid-Holocene and last glacial maximum, J. Biogeogr., 27, 635-664, 2000.

Zhang, Z., Zhao, M., Lu, H., and Faiia, A. M.: Lower temperature as the main cause of $\mathrm{C} 4$ plant declines during the glacial periods on the Chinese Loess Plateau, Earth Planet. Sci. Lett., 214, 467481, 2003.

Zheng, Z., Baoyin, Y., and Petit-Maire, N.: Paleoenvironments in China during the Last Glacial Maximum and the Holocene optimum, Episodes, 21, 152-158, 1998. 